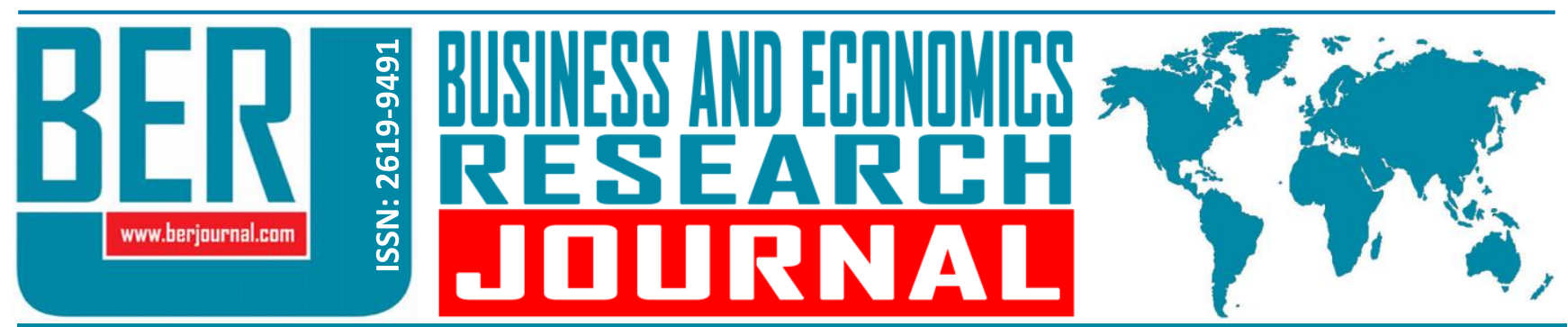

Business and Economics Research Journal Vol. 11, No. 1, 2020, pp. 119-129 doi: 10.20409/berj.2020.239

\title{
Volatility Spillover between Uncertainty in Financial and Commodity Markets and Turkish Stock Market
}

\section{Baris Kocaarslan ${ }^{a}$}

\begin{abstract}
The aim of this study is to investigate risk spillovers between uncertainty about financial and commodity markets and Turkish stock market by using a causality-invariance test. To this end, we use implied volatility indexes (the implied volatility of the gold, oil, stock, and currency prices from options markets) and Morgan Stanley Capital International (MSCl) Turkish stock market index. The volatility model estimates demonstrate that implied volatilities and Turkish stock market index are strongly influenced by long-run volatility. The causality-in-variance test results provide evidence of a significant one-way volatility spillover effect from uncertainty in financial and commodity markets to the Turkish stock market. The results suggest that Turkish stock market returns are highly sensitive to uncertainty shocks in global markets, and hence this high-sensitivity reduces the attractiveness of investments in the Turkish market. Our findings present important implications for the implementation of sound economic policies and for the formation of optimal portfolios.
\end{abstract}

Keywords: Implied Volatility, Uncertainty, Causality-inVariance, Volatility Spillover, Turkish Stock Market

JEL: C58, G15

$\begin{array}{ll}\text { Received } & : 19 \text { September } 2019 \\ \text { Revised } & : 02 \text { November } 2019 \\ \text { Accepted } & : 15 \text { November } 2019 \\ \text { Type } & : \text { Research }\end{array}$

Received : 19 September 2019 Revised : 02 November 2019 Type : Research

\section{Introduction}

The uncertain economic environment, especially in times of economic crisis, causes a significant increase in the hedging demands of investors (Bloom, 2014). Compared to developed markets, the predictability of developing market returns and volatility is more important since global investors take relatively more risks by investing in these markets. Hence, market participants need to have knowledge about to what extent information uncertainty in financial and non-financial markets affects global investors' risk appetite and about how this effect, if any, changes the relative riskiness of developing markets. Information uncertainty plays a key role in influencing developing market returns and volatility. In this study, we investigate the volatility spillovers between uncertainty about the financial and commodity markets and Turkish stock market to better understand the vulnerability of the Turkish market to global developments.

Individuals may not be able to objectively determine the probabilities of events in an uncertain environment. Ellsberg (1961) implies that individuals do not like uncertainty if they are not sure about the probability distribution of a gamble. The tendency to avoid uncertain situations is known as ambiguity aversion. The concept of uncertainty has attracted great attention in economics and finance literature because uncertain economic conditions have a big impact on the asset allocation decisions of investors. To hedge against the adverse effect of uncertainty on global portfolio returns, investors should follow dynamic learning strategies (Xia, 2001). The negative and positive effects (after bad and good news, respectively) of 
information uncertainty on stock returns lead to significant changes in portfolio compositions of investors (Zhang, 2006). The aim of diversification strategies in global markets is to reduce the systematic risk in a market. Despite the higher returns from developing markets (e.g. Turkish market), especially when compared to developed markets, the perception of higher uncertainty about the future of these markets is quite effective in influencing investors' decisions on risky assets. Therefore, implementing proper investment strategies across global markets requires investors to carefully consider the impact of uncertainty on developing markets.

A signal about the volatility expectations (and hence uncertainty) in leading commodity and financial markets alters the weight of risky assets in an optimal portfolio. The increased risk and uncertainty perceptions regarding the future economic environment are easily recognized by the investors observing price fluctuations in options markets in which the hedging activities of traders are frequently performed in a short time. Sophisticated investors and speculators (e.g. financial intermediaries) play a crucial role in options markets with the use of their superior knowledge and expertise (He et al., 2017). A significant change in hedging activities in options markets provides valuable information for the market participants with respect to worsening economic conditions. Hence, this information has a considerable social and economic role in reducing business and financial risks. Implied volatilities obtained from options markets are widely used to capture the forward-looking components of uncertainty (Christensen \& Prabhala, 1998; Fleming et al., 1998; Szakmary et al., 2003; Kellogg, 2014). The implied volatilities reflect common beliefs among market participants on the expected uncertainty. Also, implied volatility indices indicate investor sentiment since higher implied volatilities show higher fear among market players about financial turmoil (Maghyereh et al., 2016). In light of the above information, one might argue that option-implied volatilities reflecting volatility expectations in financial and non-financial markets can be used as proxies for uncertainty.

The level of exposure to option-implied stock price volatility is of primary importance in affecting the equity market returns in the US (Ang et al., 2006). It is inevitable that developing markets are influenced by the uncertainties in the developed markets (e.g. US market) due to a growing integration between global markets along with the increasing liberalization in recent years. The US market plays a central role for the global financial system (Bessler and Yang, 2003; Chowdhury, 1994). Thereby, we use the Chicago Board Options Exchange (CBOE) Volatility Index (VIX), which is obtained from S\&P 500 index options, to consider the uncertainty and fear in the US stock market (Bloom, 2014). Previous literature has pointed out that some specific assets are relatively more important among others. For instance, the US dollar, as a premier reserve and funding currency, is one of the key determinants of fluctuations in international markets (Goldberg \& Tille, 2009; Steiner, 2014; Maggiori, 2017). The increasing financialization of gold and oil markets has intensified their role in explaining financial market returns and volatility. (Diebold \& Yilmaz, 2012; Basak \& Pavlova, 2016; Mensi et al., 2017). Oil price uncertainty strongly impacts several macroeconomic indicators (e.g. investment, unemployment, consumption, production growth) (Elder \& Serletis, 2010; Kocaaslan, 2019;). Various studies indicate the hedging potential of gold, as a safe haven asset, against inflation and hence unexpected stock price changes (Baur \& Lucey, 2010; Baur \& McDermott, 2010; Chan et al., 2011; O'Connor et al., 2015). When considering these facts, one may argue that the assessment of uncertainty in oil, gold, stock and currency markets gives information about investor sentiment and consensus among market players on future market conditions. Taking into account the above discussion, for our empirical analyses, we suggest the use of implied volatility of the gold, oil, stock, and currency prices from options markets to examine volatility spillovers between uncertainty in commodity and financial markets and Turkish stock market.

There is a limited number of recent studies that concentrate on the relationship between uncertainty in stock and some commodity markets (such as oil and gold) and Turkish stock market (e.g. Kaya, 2015; Hatipoğlu \& Tekin, 2017; Öner et al., 2018; Başarır, 2018; Sadeghzadeh \& Elmas, 2018; Cihangir, 2018). However, there is a gap of knowledge on the impact of uncertainty in currency markets on the Turkish stock market. More importantly, no effort has been devoted to exploring volatility spillovers between uncertainty in commodity and financial markets and the Turkish stock market. To close this void in the literature, we use the causality-in-variance test suggested by Hafner and Herwartz (2006) due to several important advantages 
of this test explained in the "Econometric Technique" section. In this study, with the help of the causality-invariance test, we concentrate our focus on the risk spillovers between uncertainty in financial (stock and currency) and commodity markets (oil and gold) and Turkish stock market. In other words, the main purpose of using the causality-in-variance test is to better capture the uncertainty related risks in the Turkish stock market stemming from deep uncertainty (uncertainty in variation in volatility) in the financial and commodity markets.

\section{Literature Review}

The benefits of diversifying across global stock markets are based on the changes in the investment opportunity set. The risk perceptions of international investors mostly depend on changing future investment opportunities, which considerably affect the asset allocations of globally optimal portfolios (Merton, 1973). News about future market returns and volatilities is of utmost importance in determining sound risk management strategies in global markets (Chen, 2002; Campbell, 1993, 1996). In this respect, a clear understanding of which macroeconomic indicators reflect future market conditions is essential to better rebalance globally diversified portfolios over time.

As mentioned in the previous section, the volatility expectations in financial and commodity markets (option-implied volatilities) give market players an idea of the uncertainty in the aggregate market. Therefore, the mechanism of the impact of uncertainty on global markets is intriguing. The significant effect of the VIX index (which is used to represent information uncertainty in the stock market (Bloom, 2014)) on the US stock market has been documented by various studies (Ang et al., 2006; Blair et al., 2001; Becker et al., 2009). When taking into account the key role of fluctuations in the US market for global dynamics, it is highly likely that the fluctuations in the VIX index will have a strong impact on risky emerging markets.

Previous literature points to the role of global risk perceptions (VIX) and commodity markets in influencing developing countries (Hacihasanoglu et al., 2012; Ordu \& Soytas, 2016; Ewing et al., 2018). Some existing studies investigate the impact of VIX on the Turkish stock market. Korkmaz and Çevik (2009) find that the changes in the VIX index significantly affect the Turkish stock market. Using a vector error correction model, Kaya (2015) demonstrates the strong impact of the VIX on the Turkish stock market in the presence of cointegration. Hatipoğlu and Tekin (2017) present similar findings to that provided by Kaya (2015) utilizing a quantile regression framework. Öner et al. (2018) find Granger causality from the VIX to the Turkish stock market. Başarır (2018) conducts a frequency domain causality test and provides supporting evidence for the above studies. Sadeghzadeh and Elmas (2018) employ the panel autoregressive distributed lag (ARDL) model and document that the VIX is one of the most important determinants of Turkish stock market returns.

On the other hand, several studies investigate how volatility expectations (uncertainty) in gold and oil markets influence emerging stock markets. Raza et al. (2016) report negative impacts of option-implied oil and gold price volatilities on emerging stock markets in both the short- and long-term. The findings of Luo and Qin (2017) demonstrate the positive impact of oil price shocks and the negative impact of oil volatility shocks on Chinese sector returns. Bouri et al. (2017) provide evidence that greater uncertainty in gold and oil prices leads to an increase in Indian stock market volatility. Dutta et al. (2017) observe that oil price uncertainty is a determinant factor influencing the volatility and returns of African and Middle East stock markets. Using the vector error correction model, similar to the above findings, Cihangir (2018) shows the significant effect of option-implied gold and oil volatilities on some emerging stock markets including the Turkish stock market.

Overall, previous findings give an idea of the effect of volatility expectations (uncertainty) in financial and commodity markets (option-implied price volatilities) on the stock markets. However, the above studies do not test the causality in variance between uncertainty in financial and commodity markets and the Turkish stock market. Therefore, how uncertainty in variation in option-implied price volatilities influences the risk perceptions of global investors on the Turkish stock market remains unsolved. There is no empirical analysis on volatility spillovers between uncertainty in financial and commodity markets and the Turkish stock market. This paper is an attempt to fill this information gap. 


\section{Data Sources and Characteristics}

Our data set includes daily closing prices of the Turkish stock market obtained from Morgan Stanley Capital International, which is commonly preferred in the related literature. Dollar denominated-prices are used since global investors are mostly interested in dollar denominated-returns (Cho et al., 1986). To represent uncertainty in commodity and financial markets, we employ the CBOE Gold Volatility Index (GVZ, measuring 30-day volatility expectations in SPDR Gold Shares options), CBOE Crude Oil Volatility Index (OVX, measuring 30-day volatility expectations in United States Oil Fund option prices), CBOE Euro Currency Volatility Index (EVZ, measuring 30-day volatility expectations in USD/Euro exchange rate "currency share euro trust options"), and CBOE Volatility Index (VIX, measuring 30-day volatility expectations in the S\&P 500 index), collected from Chicago Board Options Exchange. The sample period is from January 3, 2011 to January 30,2019 . We focus on the post-crisis period to avoid the effect of the global financial crisis (2008) on investor perceptions because a lower degree of risk avoidance is observed during the post-crisis period (Hoffmann et al., 2013). The first differences of the logarithm of the variables are considered for the return of the Turkish stock market index and changes in the volatility expectations in the relevant markets for empirical investigation ${ }^{1}$.

Table 1. Descriptive Statistics of the Data

\begin{tabular}{|l|c|c|c|c|c|}
\hline & DLTUR & DLVIX & DLEVZ & DLOVX & DLGVZ \\
\hline Mean & -0.0004 & 0.0000 & -0.0004 & 0.0001 & -0.0003 \\
\hline Median & 0.0001 & -0.0050 & -0.0011 & -0.0035 & -0.0043 \\
\hline Maximum & 0.0875 & 0.7682 & 0.2891 & 0.4250 & 0.4807 \\
\hline Minimum & -0.1686 & -0.3141 & -0.3981 & -0.4399 & -0.3069 \\
\hline Std. Dev. & 0.0200 & 0.0783 & 0.0457 & 0.0493 & 0.0537 \\
\hline Skewness & -0.6523 & 1.1536 & -0.1663 & 0.9376 & 0.9344 \\
\hline Kurtosis & 7.9363 & 10.4364 & 8.5437 & 13.6524 & 9.8506 \\
\hline Jarque-Bera & 2206.1170 & 5130.2160 & 2610.1220 & 9900.2270 & 4267.0140 \\
\hline Probability & 0.0000 & 0.0000 & 0.0000 & 0.0000 & 0.0000 \\
\hline
\end{tabular}

Note: Table 1 shows descriptive statistics of the time series. $D$ and $L$ represent the first difference and log operators, respectively. DLTUR, DLVIX, DLEVZ, DLOVX, and DLGVZ represent the daily returns of the Turkish stock market prices and the implied volatilities in the stock, currency, oil and gold markets, respectively.

Table 1 reports the descriptive statistics of the returns of the Turkish stock market index and changes in implied volatilities. The statistics show the skewness and excess kurtosis for the time series. These departures from the normality assumption are confirmed by the Jarque-Bera statistic rejecting the null hypothesis of normality. Implied volatilities of option prices have higher standard deviations indicating higher volatility than the Turkish stock market index. Figure 1 illustrates the evolution of the returns in the Turkish stock market and the changes in implied volatilities over the sample period. This illustration clearly indicates the presence of heteroscedasticity and volatility clustering and hence supports the use of GARCH models to examine the relationship between the Turkish stock market and uncertainty in financial and commodity markets (implied volatilities). 
Figure 1. Evolution of the Related Index Changes Over the Period

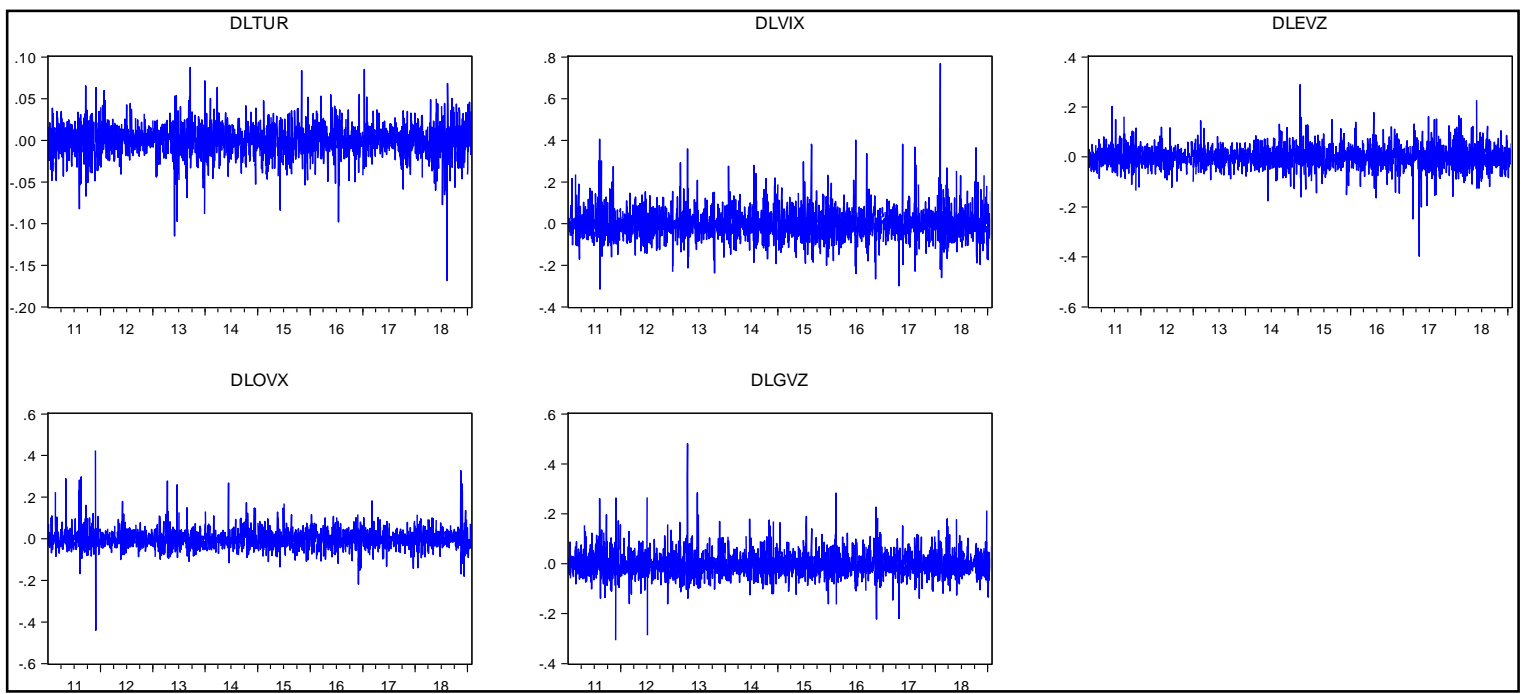

Note: $\mathrm{D}$ and $\mathrm{L}$ represent the first difference and log operators, respectively. DLTUR, DLVIX, DLEVZ, DLOVX, and DLGVZ represent the daily returns of the Turkish stock market prices and the implied volatilities in the stock, currency, oil and gold markets, respectively.

\section{Econometric Technique}

In this study, we concentrate our effort on volatility linkages to investigate information transmission between the variables of interest. This investigation enables us to understand risk spillovers between uncertainty in the US markets (including commodity and financial markets) and the Turkish stock market. The role of global risk perceptions, which depends on the volatility expectations (uncertainty) in commodity and financial markets, is of immense importance for the asset allocation decisions of global investors. These decisions on diversification strategies influence the resilience of developing markets (e.g. Turkish market) to adverse global shocks.

In order to examine the presence and direction of volatility transmissions between the uncertainty in financial and commodity markets and the Turkish stock market, we utilize the causality-in-variance test, introduced by Hafner and Herwartz (2006). In the literature, earlier causality-in-variance tests proposed by Cheung and Ng (1996) and Hong (2001) are commonly utilized to examine volatility linkages across global markets. These tests are based on the cross-correlation functions (CCFs) of the standardized residuals obtained from univariate general autoregressive conditional heteroscedasticity (GARCH) models and are sensitive to significant oversizing, for particularly small samples in the presence of the leptokurtic volatility processes (Hafner \& Herwartz, 2006). Also, the sensitivity of these tests to the selected order of leads and lags is very high. The causality-in-variance test suggested by Hafner and Herwartz (2006) is grounded on the Lagrange multiplier (LM) principle and overcomes the above-mentioned problems that the earlier tests face. By taking into consideration leptokurtic innovations in small samples and using a Monte Carlo simulation, Hafner and Herwartz (2006) indicate the robustness of the LM-based causality-in-variance test approach.

The first step of the causality-in-variance test requires the estimation of univariate GARCH models to explain the variation in the conditional means and variances ${ }^{2}$. We apply a traditional GARCH model (Bollerslev, 1986) for the conditional variance ${ }^{3}$. The specification of the variance equation of the GARCH $(1,1)$ model is indicated as follows:

$$
\sigma_{t}^{2}=\omega+\alpha \varepsilon_{t-1}^{2}+\beta \sigma_{t-1}^{2}
$$


The $\alpha$ (ARCH parameter) measures the effect of previous shocks (lagged squared errors) on current conditional variance as the $\beta$ (GARCH parameter) measures the effect of previous conditional variance (lagged conditional variance) on current conditional variance. Moreover, the sum of the GARCH and ARCH parameters $(\beta+\alpha)$ indicates the degree of volatility persistence. For stability and stationarity, some constraints ( $\omega>0 ; \alpha \geq 0 ; \beta \geq 0 ; \alpha+\beta>1$ ) should be satisfied for the GARCH models.

The second step involves testing the below null hypothesis of non-causality-in-variance between implied volatilities (series i "volatility expectations (uncertainty) in financial and commodity markets") and Turkish stock market (series j).

$$
\mathrm{H}_{0}: \operatorname{Var}\left(\varepsilon_{\mathrm{it}} \mid \mathrm{F}_{\mathrm{t}-1}^{(\mathrm{j})}\right)=\operatorname{Var}\left(\varepsilon_{\mathrm{it}} \mid \mathrm{F}_{\mathrm{t}-1}\right) \quad \mathrm{j}=1, \ldots, \mathrm{N}, \mathrm{i} \neq \mathrm{j},
$$

Where $\mathrm{F}_{\mathrm{t}}^{(\mathrm{j})}=\mathrm{F}_{\mathrm{t}} / \sigma\left(\varepsilon_{\mathrm{j} \tau}, \tau \leq \mathrm{t}\right)$ and $\varepsilon_{\mathrm{it}}$ represents the residuals obtained from the standard univariate $\mathrm{GARCH}$ model. The following equation is considered to test the null hypothesis:

$$
\varepsilon_{\mathrm{it}}=\xi_{\mathrm{it}} \sqrt{\sigma_{\mathrm{it}}^{2}\left(1+\mathrm{z}_{\mathrm{jt}}^{\prime} \pi\right)} \quad, \quad \mathrm{z}_{\mathrm{jt}}=\left(\varepsilon_{\mathrm{jt}-1}^{2}, \sigma_{\mathrm{jt}-1}^{2}\right)^{\prime},
$$

$\sigma_{\text {it }}^{2}$ and $\xi_{\text {it }}$ refer respectively to the conditional volatility (variance) and the standardized residuals for the series $\mathrm{i}$ while $\sigma_{\mathrm{jt}-1}^{2}$ and $\varepsilon_{\mathrm{jt}-1}^{2}$ refer respectively to the conditional volatility (variance) and the squared standardized residuals for the series $\mathrm{j}$. The null hypothesis $\mathrm{H}_{0}: \pi=0$ (no causality-in-variance) is tested against the alternative hypothesis $H_{1}: \pi \neq 0$ stating the existence of the causality. The score of the Gaussian loglikelihood function of $\varepsilon_{\mathrm{it}}$ is derived by $\mathrm{x}_{\mathrm{it}}\left(\xi_{\mathrm{it}-1}^{2}\right) / 2$, where the derivatives are $\mathrm{x}_{\mathrm{it}}=\sigma_{\mathrm{it}}^{-2}\left(\partial \sigma_{\mathrm{it}}^{2} / \partial \theta_{\mathrm{i}}\right), \theta_{\mathrm{i}}=$ $\left(\omega_{i}, \alpha_{i}, \beta_{i}\right)^{\prime}$. Hafner and Herwartz (2006) propose the below LM test to explore volatility linkages between the related variables.

$$
\begin{aligned}
& \lambda_{\mathrm{LM}}=\frac{1}{4 \mathrm{~T}}\left(\sum_{\mathrm{t}=1}^{\mathrm{T}}\left(\xi_{\mathrm{it}}^{2}-1\right) \mathrm{z}^{\prime}{ }_{\mathrm{jt}}\right) \mathrm{V}\left(\theta_{\mathrm{i}}\right)^{-1}\left(\sum_{\mathrm{t}=1}^{\mathrm{T}}\left(\xi_{\mathrm{it}}^{2}-1\right) \mathrm{z}_{\mathrm{jt}}\right), \\
& \mathrm{V}\left(\theta_{\mathrm{i}}\right)=\frac{\mathrm{K}}{4 \mathrm{~T}}\left(\sum_{\mathrm{t}=1}^{\mathrm{T}} \mathrm{z}_{\mathrm{jt}} \mathrm{z}^{\prime}{ }_{\mathrm{jt}}-\sum_{\mathrm{t}=1}^{\mathrm{T}} \mathrm{z}_{\mathrm{jt}} \mathrm{x}^{\prime}{ }_{\mathrm{it}}-\left(\sum_{\mathrm{t}=1}^{\mathrm{T}} \mathrm{x}_{\mathrm{it}} \mathrm{x}^{\prime}{ }_{\mathrm{it}}\right)^{-1} \sum_{\mathrm{t}=1}^{\mathrm{T}} \mathrm{x}_{\mathrm{it}} \mathrm{z}^{\prime}{ }_{\mathrm{jt}}\right), \\
& \mathrm{K}=\frac{1}{\mathrm{~T}}\left(\sum_{\mathrm{t}=1}^{\mathrm{T}}\left(\xi_{\mathrm{it}}^{2}-1\right)^{2}\right)
\end{aligned}
$$

The asymptotic distribution of the test statistic in Eq. (4) is based on the number of misspecification indicators in $\mathrm{z}_{\mathrm{jt}}$. The presence of two misspecification indicators in $\lambda_{\mathrm{LM}}$ equation requires us to obtain an asymptotic chi-square distribution with two degrees of freedom, which is the best fitting distribution for the used models. Rejecting the null hypothesis shows a volatility spillover from series $\mathrm{j}$ to series $\mathrm{i}$. A similar procedure is followed to investigate volatility spillover from series $i$ to series $j$.

\section{Empirical Findings and Discussion}

As mentioned in the previous section, univariate GARCH $(1,1)$ models are estimated to follow the steps of the causality-in-variance test procedure. Tables 2 and 3 report the results for the mean and variance equations of the GARCH models, respectively. Before the interpretation of parameters, we need to control whether the stability conditions $(\omega>0 ; \alpha \geq 0 ; \beta \geq 0 ; \alpha+\beta>1$ ) are satisfied or not. A quick check shows that the estimated GARCH model results confirm the satisfied stability requirements. The significant $A R(1)$ terms in the mean equations suggest that implied volatilities in the stock, currency, and gold markets are significantly and negatively influenced by their own lags. The significant statistical parameters in the variance equations clearly indicate the existence of conditional heteroscedasticity for all variables. The greater long- 
run $(\mathrm{GARCH})$ effect than the short-run $(\mathrm{ARCH})$ effect is observed for the indices, which implies strong longrun volatility ${ }^{4}$.

Table 2. Mean Equation Results

\begin{tabular}{cccccc}
\hline $\begin{array}{c}\text { Independent } \\
\text { Variables }\end{array}$ & \multicolumn{5}{c}{ Dependent Variables } \\
\hline DLTUR & DLVIX & DLEVZ & DLOVX & DLGVZ \\
\hline Constant & 0.0002 & 0.000287 & -0.000922 & -0.00038 & -0.000487 \\
AR(1) & 0.02133 & $-0.065795^{* *}$ & $-0.053136^{* *}$ & -0.00501 & $-0.074322^{* * *}$ \\
\hline
\end{tabular}

Note: Table 2 reports the estimated coefficients in the mean equations for the time series. $D$ and $L$ represent the first difference and log operators, respectively. DLTUR, DLVIX, DLEVZ, DLOVX, and DLGVZ represent the daily returns of the Turkish stock market prices and the implied volatilities in the stock, currency, oil and gold markets, respectively. Dependent variables are the DLTUR, DLVIX, DLEVZ, DLOVX, and DLGVZ. Explanatory variables are the lagged changes (AR(1) term). ${ }^{* *}$ Significant at the $5 \%$ level; ${ }^{* * *}$ significant at the $1 \%$ level.

Table 3. Variance Equation Results

\begin{tabular}{ccccc}
\hline $\begin{array}{c}\text { Dependent } \\
\text { Variable }\end{array}$ & Model chosen & $\omega$ & $\alpha$ & $\beta$ \\
\hline DLTUR & GARCH(1,1) & $1.06 \mathrm{E}-05^{* * *}$ & $0.063595^{* * *}$ & $0.911903^{* * *}$ \\
DLVIX & GARCH(1,1) & $0.001296^{* * *}$ & $0.168243^{* * *}$ & $0.619550^{* * *}$ \\
DLEVZ & GARCH(1,1) & $1.90 \mathrm{E}-05^{* * *}$ & $0.016925^{* * *}$ & $0.974316^{* * *}$ \\
DLOVX & GARCH(1,1) & $0.000374^{* * *}$ & $0.109277^{* * *}$ & $0.733740^{* * *}$ \\
DLGVZ & GARCH(1,1) & $0.000466^{* * *}$ & $0.140277^{* * *}$ & $0.698602^{* * *}$ \\
\hline
\end{tabular}

Note: Table 3 reports the estimated coefficients in the variance equations for the GARCH $(1,1)$ model. $* * *$ Significant at the $1 \%$ level. DLTUR, DLVIX, DLEVZ, DLOVX, and DLGVZ represent the daily returns of the Turkish stock market prices and the implied volatilities in the stock, currency, oil and gold markets, respectively. $\alpha$ and $\beta$ represent the ARCH and GARCH parameters, respectively.

The presence of the persistent long-run volatility encourages us to investigate the volatility transmission between uncertainty in financial and commodity markets and Turkish stock market returns. Table 4 reports the causality-in-variance (volatility spillover) test results. We find strong evidence of one-way causality-in-variance (volatility spillover effect) from implied volatilities in the stock, currency, oil, and gold markets to the Turkish stock market. This finding supports the high sensitivity of the Turkish market to uncertainties in global markets including both financial and commodity markets.

Our results show that there is a strong risk spillover from uncertainty in the US stock market to the Turkish stock market (in other words, the strong impact of deep uncertainty in the US stock market on the riskiness of the Turkish stock market). With increasing globalization, investment tendencies in risky markets (e.g. emerging markets) have increased recently. However, a decline in global investors' risk appetite leads to a decline in the investment tendencies in these markets. An increase in volatility expectations in the US stock market is an important indicator of deteriorated future market conditions for market players. Therefore, this increase has a negative effect on investor sentiment and hence on global risk appetite. Our empirical results, as expected, suggest that this negative effect increases the risk perceptions towards investments in the Turkish stock market.

We also find a causality-in-variance from uncertainty in the currency market (the euro-dollar rate) to the Turkish stock market. The import and export of Turkey are expected to be significantly affected by the euro-dollar rate. The reason behind this effect is that a significant part of Turkeys' export is based on the use of the Euro-currency while the import mostly depends on the use of the US dollar. Also, these main currencies are of central importance in influencing some macroeconomic indicators in Turkey (e.g. inflation and interest 
rates). Another explanation could be the high rate of foreign currency debts Turkish companies have. In light of this information, it is not surprising that a deep uncertainty in the euro-dollar rate amplifies the risk level of the investments in the Turkish market.

Table 4. Volatility Spillover Test Results (LM Test Statistics)

\begin{tabular}{|c|c|c|c|c|c|}
\hline & DLTUR & DLVIX & DLEVZ & DLOVX & DLGVZ \\
\hline DLTUR & & $10.58416^{* * *}$ & $10.45255^{* * *}$ & $12.16634^{* * *}$ & $11.02866 * * *$ \\
\hline DLVIX & 3.978 & & & & \\
\hline DLEVZ & 2.8783 & & & & \\
\hline DLOVX & 4.6628 & & & & \\
\hline DLGVZ & 3.4948 & & & & \\
\hline
\end{tabular}

Notes: Table 4 reports the causality-in-variance test results. DLTUR, DLVIX, DLEVZ, DLOVX, and DLGVZ represent the daily returns of the Turkish stock market prices and the implied volatilities in the stock, currency, oil and gold markets, respectively. Significance implies Granger causality in variance running from column variable to row variable. ${ }^{* * *}$ Significant at the 1 percent level.

As for the impact of uncertainty in oil markets, we observe a significant volatility spillover from oil price uncertainty to the Turkish stock market. There are various potential reasons for this result. Oil price uncertainty plays a crucial role in economic activity through its adverse impacts on aggregate output, investment, and unemployment (Elder \& Serletis, 2010; Kocaaslan, 2019). Also, an increase in volatility expectations in oil markets generates increased inflationary pressure (Awartani et al., 2016). To this respect, it is very likely that increased uncertainty in oil prices has a big impact on business cycles and ultimately on stock prices. The Turkish economy, as an oil-importing economy, is highly vulnerable to developments in oil markets. Therefore, the level of oil price uncertainty is of immense importance in increasing the riskiness of the portfolios including assets in the Turkish market.

An additional result of our analysis is that there is a strong volatility spillover effect from uncertainty in gold prices to the Turkish stock market. Gold is widely preferred by investors to hedge unexpected inflation risk under worsening economic conditions and thus to hedge unexpected stock price fluctuations (Baur \& McDermott, 2010; Baur \& Lucey, 2010). Due to these safe-haven properties of gold, increased speculative trading in options markets and consequently an increase in gold price uncertainty indicates inflationary expectations and uncertain monetary policy actions in the near future. Based on these facts, one could argue that increased implied volatility (increased uncertainty) in gold prices leads global investors to alter the asset allocation of their portfolios for hedging purposes. The changing composition of global portfolios causes an increase in the volatility of risky markets (e.g. Turkish market).

\section{Conclusion}

A change in the level of volatility of a market includes newly transmitted information for the market. This new information could be related to heightened uncertainty in global markets including financial and commodity markets. Therefore, it is highly important to uncover volatility spillovers between uncertainty in financial and commodity markets and stock markets for volatility forecasting, asset valuation and hence for forming optimal global portfolios. Exploring the direction of information flows between uncertainty in global markets and stock markets helps to improve risk management strategies. In contrast with the previous studies, we aim to discover the extent to which uncertainty shocks in global markets are transmitted to the Turkish stock market in which the proportion of foreign investors is sufficiently large to make it more sensitive to global developments. To this end, we study volatility linkages between uncertainty about commodity and financial markets and the Turkish stock market. We do that by employing the causality-in-variance test introduced by Hafner and Herwartz (2006).

Our findings suggest a significant volatility spillover effect from uncertainty in financial and commodity markets to the Turkish stock market. In other words, uncertainty in variation in volatility (deep uncertainty) of the global markets has a substantial impact on the riskiness of the Turkish market. On one 
hand, from a perspective of risk management strategies, the findings are very valuable because they inform global investors about the risk level of the Turkish stock market associated with uncertainty shocks in global markets, which lead to the reduced diversification potential of assets in the Turkish market. On the other hand, from an economic policy perspective, our results are of vital importance for the determination of sound economic policies. Economic policymakers in Turkey should pay considerable attention to the changing volatility expectations in commodity and financial markets in order to diminish the vulnerability of the Turkish market to deep uncertainty in global markets. For example, they can inform market participants about the effective use of monetary policy instruments during a period of high uncertainty. Improving the transparency of monetary policy is of paramount importance in reducing information asymmetries between monetary policymakers and market players (Geraats, 2006). In this respect, central bank communication is an important element of influence in the monetary policy process. To improve the transparency of this communication, as Geraats (2006) points out, monetary policymakers should take into account the wording of policy statements. In light of this information, it could be suggested that predictable and effective monetary policy actions taken by monetary policymakers in Turkey (less uncertainty about monetary policy goals) reduce the sensitivity of the Turkish stock market to uncertainty shocks in financial and commodity markets.

For future research, volatility linkages between uncertainty about the commodity and financial markets and other developing and/or developed markets in different regions (e.g. MENA markets) might be further investigated. Also, further research might focus on examining the risk transmissions between uncertainty in global markets and industry-level index returns in the developed and/or developing markets.

\section{End Notes}

1. The causality-in-variance test requires that the variables should be stationary. To meet this requirement, we use the first differences of the logarithm of the variables. To make sure, we also conduct some unit root tests (e.g. DickeyFuller GLS detrended test (DF-GLS) (Elliot et al., 1996) and the modified augmented Dickey-Fuller (MADF) test (Kim \& Perron, 2009) accounting for a structural breakpoint). Results confirm that all variables are stationary. For brevity, the results are not reported here and are provided upon request.

2. We do not explain the GARCH model in detail because the focal point of the study is to test the causality-in-variance between the variables of interest. For a detailed exposition of the GARCH model, please see Bollerslev (1986).

3. We include $A R(1)$ term in the conditional mean equation to eliminate serial correlation in time series and to capture the speed of the reflected market information on the level of the indexes.

4. We also carry out various diagnostic tests for robustness and do not find a significant problem. The findings are provided upon request.

\section{References}

Ang, A., Hodrick, R. J., Xing, Y., \& Zhang, X. (2006). The cross-section of volatility and expected returns. The Journal of Finance, 61(1), 259-299.

Awartani, B., Aktham, M., \& Cherif, G. (2016). The connectedness between crude oil and financial markets: Evidence from implied volatility indices. Journal of Commodity Markets, 4(1), 56-69.

Basak, S., \& Pavlova, A. (2016). A model of financialization of commodities. The Journal of Finance, 71(4), $1511-1556$.

Başarır, Ç. (2018). Korku endeksi (VIX) ile BIST 100 arasındaki ilişki: Frekans alanı nedensellik analizi. Dokuz Eylül Üniversitesi İsletme Fakültesi Dergisi, 19(2), 177-191.

Baur, D. G., \& Lucey, B. M. (2010). Is gold a hedge or a safe haven? An analysis of stocks, bonds and gold. Financial Review, 45(2), 217-229.

Baur, D. G., \& McDermott, T. K. (2010). Is gold a safe haven? International evidence. Journal of Banking \& Finance, 34(8), 1886-1898.

Becker, R., Clements, A. E., \& McClelland, A. (2009). The jump component of S\&P 500 volatility and the VIX index. Journal of Banking \& Finance, 33(6), 1033-1038. 
Bessler, D. A., \& Yang, J. (2003). The structure of interdependence in international stock markets. Journal of International Money and Finance, 22(2), 261-287.

Blair, B. J., Poon, S. H., \& Taylor, S. J. (2001). Forecasting S\&P 100 volatility: The incremental information content of implied volatilities and high-frequency index returns. Journal of Econometrics, 105(1), 5-26.

Bloom, N. (2014). Fluctuations in uncertainty. Journal of Economic Perspectives, 28(2), 153-76.

Bollerslev, T. (1986). Generalized autoregressive conditional heteroskedasticity. Journal of Econometrics, 31(3), 307327.

Bouri, E., Jain, A., Biswal, P. C., \& Roubaud, D. (2017). Cointegration and nonlinear causality amongst gold, oil, and the Indian stock market: Evidence from implied volatility indices. Resources Policy, 52, 201-206.

Campbell, J. Y. (1993). Intertemporal asset pricing without consumption data. The American Economic Review, 83(3), 487-512.

Campbell, J. Y. (1996). Understanding risk and return. Journal of Political Economy, 104(2), 298-345.

Chan, K. F., Treepongkaruna, S., Brooks, R., \& Gray, S. (2011). Asset market linkages: Evidence from financial, commodity and real estate assets. Journal of Banking \& Finance, 35(6), 1415-1426.

Chen, J. (2002, May). Intertemporal CAPM and the cross-section of stock returns. EFA 2002 Berlin Meetings Discussion Paper.

Cheung, Y. W., \& Ng, L. K. (1996). A causality-in-variance test and its application to financial market prices. Journal of Econometrics, 72(1-2), 33-48.

Cho, D. C., Eun, C. S., \& Senbet, L. W. (1986). International arbitrage pricing theory: An empirical investigation. The Journal of Finance, 41(2), 313-329.

Chowdhury, A. R. (1994). Stock market interdependencies: Evidence from the Asian NIEs. Journal of Macroeconomics, 16(4), 629-651.

Christensen, B. J., \& Prabhala, N. R. (1998). The relation between implied and realized volatility. Journal of Financial Economics, 50(2), 125-150.

Cihangir, Ç. K. (2019). The Effect of commodity volatility indexes and FED fund rates on the stock market indices of developing countries. Muhasebe ve Finansman Dergisi, 81, 293-314.

Diebold, F. X., \& Yilmaz, K. (2012). Better to give than to receive: Predictive directional measurement of volatility spillovers. International Journal of Forecasting, 28(1), 57-66.

Dutta, A., Nikkinen, J., \& Rothovius, T. (2017). Impact of oil price uncertainty on Middle East and African stock markets. Energy, 123, 189-197.

Elder, J., \& Serletis, A. (2010). Oil price uncertainty. Journal of Money, Credit and Banking, 42(6), 1137-1159.

Elliot, B. E., Rothenberg, T. J., \& Stock, J. H. (1996). Efficient tests of the unit root hypothesis. Econometrica, 64(8), 1336.

Ellsberg, D. (1961). Risk, ambiguity, and the savage axioms. The Quarterly Journal of Economics, 75(4), 643-669.

Ewing, B. T., Gormus, A., \& Soytas, U. (2018). Risk transmission from oil and natural gas futures to emerging market mutual funds. Emerging Markets Finance and Trade, 54(8), 1827-1836.

Fleming, J., Kirby, C., \& Ostdiek, B. (1998). Information and volatility linkages in the stock, bond, and money markets. Journal of Financial Economics, 49(1), 111-137.

Geraats, P. M. (2006). Transparency of monetary policy: Theory and practice. CESifo Economic Studies, 52(1), 111-152.

Goldberg, L., \& Tille, C. (2009). Macroeconomic interdependence and the international role of the dollar. Journal of Monetary Economics, 56(7), 990-1003.

Hacihasanoglu, E., Simga-Mugan, F. C., \& Soytas, U. (2012). Do global risk perceptions play a role in emerging market equity return volatilities? Emerging Markets Finance and Trade, 48(4), 67-78.

Hafner, C. M., \& Herwartz, H. (2006). A Lagrange multiplier test for causality in variance. Economics Letters, 93(1), 137141.

Hatipoğlu, M., \& Tekin, B. (2017). The effects of VIX index, exchange rate \& oil prices on the BIST 100 Index: A quantile regression approach. Ordu Üniversitesi Sosyal Bilimler Araştırmaları Dergisi, 7(3), 627-634.

He, Z., Kelly, B., \& Manela, A. (2017). Intermediary asset pricing: New evidence from many asset classes. Journal of Financial Economics, 126(1), 1-35. 
Hoffmann, A. O., Post, T., \& Pennings, J. M. (2013). Individual investor perceptions and behavior during the financial crisis. Journal of Banking \& Finance, 37(1), 60-74

Hong, Y. (2001). A test for volatility Spillover with application to exchange rates. Journal of Econometrics, 103(1-2), 183224.

Kaya, E. (2015). Borsa İstanbul (BIST) 100 endeksi ile Zımni Volatilite (VIX) endeksi arasındaki eş-bütünleşme ve Granger nedensellik. Karamanoğlu Mehmetbey Üniversitesi Sosyal ve Ekonomik Araştırmalar Dergisi, 2015(1), 1-6.

Kellogg, R. (2014). The effect of uncertainty on investment: Evidence from Texas oil drilling. American Economic Review, 104(6), 1698-1734.

Kim, D., \& Perron, P. (2009). Unit root tests allowing for a break in the trend function at an unknown time under both the null and alternative hypotheses. Journal of Econometrics, 148(1), 1-13.

Kocaaslan, O. K. (2019). Oil price uncertainty and unemployment. Energy Economics, 81, 577-583.

Korkmaz, T., \& Çevik, E. İ. (2009). Zımni volatilite endeksinden gelişmekte olan piyasalara yönelik volatilite yayılma etkisi. BDDK Bankacilik ve Finansal Piyasalar, 3(2), 87-105.

Luo, X., \& Qin, S. (2017). Oil price uncertainty and Chinese stock returns: New evidence from the oil volatility index. Finance Research Letters, 20, 29-34.

Maggiori, M. (2017). Financial intermediation, international risk sharing, and reserve currencies. American Economic Review, 107(10), 3038-71.

Maghyereh, A. I., Awartani, B., \& Bouri, E. (2016). The directional volatility connectedness between crude oil and equity markets: New evidence from implied volatility indexes. Energy Economics, 57, 78-93.

Mensi, W., Hammoudeh, S., Shahzad, S. J. H., \& Shahbaz, M. (2017). Modeling systemic risk and dependence structure between oil and stock markets using a variational mode decomposition-based copula method. Journal of Banking \& Finance, 75, 258-279.

Merton, R. C. (1973). An intertemporal capital asset pricing model. Econometrica, 41(5), 867-887.

O'Connor, F. A., Lucey, B. M., Batten, J. A., \& Baur, D. G. (2015). The financial economics of gold-a survey. International Review of Financial Analysis, 41, 186-205.

Ordu, B. M., \& Soytaş, U. (2016). The relationship between energy commodity prices and electricity and market index performances: Evidence from an emerging market. Emerging Markets Finance and Trade, 52(9), 2149-2164.

Öner, H., İçellioğlu, C. Ş., \& Öner, S. (2018). Volatilite endeksi (VIX) ile gelişmekte olan ülke hisse senedi piyasası endeksleri arasındaki Engel-Granger eş-bütünleşme ve Granger nedensellik analizi. Finansal Araştırmalar ve Çalışmalar Dergisi, 10(18), 110-124.

Raza, N., Shahzad, S. J. H., Tiwari, A. K., \& Shahbaz, M. (2016). Asymmetric impact of gold, oil prices and their volatilities on stock prices of emerging markets. Resources Policy, 49, 290-301.

Sadeghzadeh, K., \& Elmas, B. (2018). Makroekonomik faktörlerin hisse senedi getirilerine etkilerinin BIST'de araştırılması. Muhasebe ve Finansman Dergisi, (80), 207-232.

Steiner, A. (2014). Current account balance and dollar standard: Exploring the linkages. Journal of International Money and Finance, 41, 65-94.

Szakmary, A., Ors, E., Kim, J. K., \& Davidson III, W. N. (2003). The predictive power of implied volatility: Evidence from 35 futures markets. Journal of Banking \& Finance, 27(11), 2151-2175.

Xia, Y. (2001). Learning about predictability: The effects of parameter uncertainty on dynamic asset allocation. The Journal of Finance, 56(1), 205-246.

Zhang, X. F. (2006). Information uncertainty and stock returns. The Journal of Finance, 61(1), 105-137. 
This Page Intentionally Left Blank 